\title{
Mortality determiners for fall from height cases
}

\author{
Muzaffer Akkoca, M.D., ๑ Serhat Tokgöz, M.D., ৫ Kerim Bora Yılmaz, M.D., ๑ Sümeyra Güler, M.D., \\ ㄴ) Melih Akıncı, M.D., ๑ Şener Balas, M.D., ๑ Harun Karabacak, M.D., @ Mehmet Saydam, M.D.
}

Department of General Surgery, University of Health Sciences, Dışkapı Training and Research Hospital, Ankara-Turkey

\begin{abstract}
BACKGROUND: The aim of the present study was to investigate the role of body mass index (BMI) and trauma severity score systems on the mortality rates of patients undergoing surgery due to falls from height.

METHODS: This retrospective study included 45 consecutive adult patients with multitrauma who were admitted and operated on due to a fall from height between January 2008 and December 2016. Patients were divided into mortality and recovery groups ( $\mathrm{n}=10$ and $n=35$, respectively). The groups were compared in terms of age, gender, weight, cause of the fall, height of the fall, location of the fall, BMI, trauma scores (Injury Severity Score [ISS], New Injury Severity Score [NISS], Glasgow Coma Scale [GCS], Abbreviated Injury Score [AIS], Revised Trauma Score [RTS]), hospital stay, and postoperative complications.

RESULTS: There was no statistically significant difference between the two groups in terms of age, gender, and height or cause of the fall $(p>0.05)$, whereas there was a statistically significant difference with respect to weight and BMI values $(p<0.01)$. A statistically significant difference was determined between the groups in terms of hospital stay and postoperative complications ( $p<0.0 \mathrm{I})$ and ISS, NISS, GCS, AIS, and RTS scores $(p<0.05)$.
\end{abstract}

CONCLUSION: The effect of weight and BMI on the mortality rate of patients presenting with trauma as a result of a fall from height was objectively demonstrated in the present study.

Keywords: Body mass index; fall from height; mortality; Trauma Score.

\section{INTRODUCTION}

Trauma is one of the major causes of death among the young population, resulting in approximately 6 million deaths each year. ${ }^{[1]}$ Approximately $80 \%$ of mortality between the ages of 15-24 years is caused by trauma. ${ }^{[2]}$ Although a fall from height is more likely to be accidental, it can also be due to suicide or criminal reasons. The causes of falls from height vary in every age group. The severity of trauma depends on many factors, such as the height of the fall, the speed of deceleration, the composition of the impact surface, other objects impacted during the fall, the part of the body initially affected, and individual factors, such as age, body weight, and comorbidities. ${ }^{[3,4]}$

Trauma scoring systems (TSSs) are widely used for cases of falls from height that may have considerably complex and heterogeneous pathophysiological patterns and different demographic factors, such as age, gender, and etiology. Methodologically, TSSs evaluate the severity of injury, including the anatomical severity and the level of physiological disorder, and convert the results into numerical data. These systems can determine the hospital stay and mortality rates, transfer suitable patients to proper facilities at the right time, compare large series, and eventually provide analyses of trauma care outcomes. ${ }^{[5]}$ The purpose of establishing TSSs is to define the objective and comparable criteria for the determination of the severity of an injury. Anatomical location, physiological parameters, and trauma mechanisms are the three essential criteria to define the severity of an injury and also predict outcome. Moreover, these expedite the evaluation of various combinations of scoring systems. ${ }^{[6]}$

Cite this article as: Akkoca M, Tokgöz S, Yılmaz KB, Güler S, Akıncı M, Balas Ş, et al. Mortality determiners for fall from height cases. Ulus Travma Acil Cerrahi Derg 2018;24:445-449.

Address for correspondence: Muzaffer Akkoca, M.D.

SBÜ Dışkapı Yıldııım Beyazıt Eğitim ve Araştırma Hastanesi, Genel Cerrahi Kliniği, Ankara, Turkey

Tel: +90 312 - 5962312 E-mail: muzafferakk@gmail.com

Ulus Travma Acil Cerrahi Derg 2018;24(5):445-449 DOI: 10.5505/tjtes.2018.50724 Submitted: 04.12.2017 Accepted: 22.03.2018 Online: 10.09.2018

Copyright 2018 Turkish Association of Trauma and Emergency Surgery 
The aim of the present study was to investigate patients who had fallen from height and who were operated on immediately due to hemodynamic instability. Evaluation was made of the reason for the fall, the severity of injury, the treatment methods, and the effects of trauma scores, such as Injury Severity Score (ISS), New Injury Severity Score (NISS), Abbreviated Injury Score (AIS), and Revised Trauma Score (RTS), on the overall morbidity and mortality rates of patients with multitrauma who were admitted and underwent surgery in the General Surgery Service.

\section{MATERIALS AND METHODS}

This retrospective study included a total of 48 consecutive patients with multitrauma resulting from a fall from height who were admitted and operated on between January 2008 and December 2016 in Dışkapı Yıldırım Beyazıt Research and Training Hospital General Surgery Service. The local ethics committee approved the study. The descriptive data of the patients, such as age, gender, weight, reason for the fall, height of the fall, and location of the fall, were analyzed. Three cases with incomplete data were excluded from the study. All the patient records, including primary and secondary surveys, judicial case reports, autopsy reports, clinical findings, and consultation and operation notes were analyzed. Guided by these data, the severity of injury of the head, cervical, maxillofacial, thoracal, abdominal, and extremity was registered, and then body mass index (BMI), ISS, NISS, RTS, AIS, and Glasgow Coma Scale (GCS) were calculated. A record was made of which organs were injured and what type of operations was performed. Patients with blunt abdominal trauma who were operated in the General Surgery Clinic were included in the study. Patients with multitrauma were separated into two groups according to outcome, as exitus (mortality group) and healed cases (recovery group). Statistical comparisons were made between the two groups with respect to demographic variables, BMI, trauma scores (ISS, NISS, GCS, RTS, and AIS), hospital stay (days), and complications.

\section{Statistical Analysis}

Data obtained in the study were statistically analysed using the IBM SPSS II.5 software. (Chicago, USA) Mean, standard deviation, median, and minimum and maximum values were given for descriptive statistics related to continuous data, and number and percentage values were given for discrete data. The Mann-Whitney $U$ test was used for comparison of discharge status (mortality or recovery) with the data obtained by measurement and trauma scores (age, BMI, etc.), and the chi-square test or Fisher's exact test was used for comparison of data with the cut-off variables.

The statistical power of separating the deceased and the recovered cases by ISS, NISS, AIS, and RTS scores was compared by the area under the receiver operating characteristic (ROC) curve. The best cut-off point was calculated using
Youden's index. A p value of $<0.05$ was accepted as statistically significant.

\section{Limitations}

The major limitation of the present study was the inclusion of only fall from height patients operated on by the General Surgery Department and the exclusion of non-operated patients or those who were operated on by other clinics while being followed up by a general surgery department simultaneously. The primary consideration was to choose and evaluate the most vulnerable group for morbidity and mortality who required any urgent surgery at the time of diagnosis due to unstable hemodynamics.

\section{RESULTS}

Forty-five multitrauma cases were included in the study. Table I shows the gender, age, reason for the fall, length of hospital stay, weight, and BMI of the patients.

Table 2 shows the abdominal trauma present in all cases, injury regions, and grade of injuries.

The mean ISS, NISS, GCS, AIS, and RTS scores of all cases were $32 \pm 15.8,35 \pm 18.2,13 \pm 2.8,3.24 \pm 0.92$, and $7 \pm 1.2$, respectively. The most common finding due to abdominal trauma was laceration of the spleen $(n=24,53.3 \%)$, followed

Table I. Demographic data of patients with abdominal injury

\begin{tabular}{lcc}
\hline & $\mathbf{n}$ & $\%$ \\
\hline $\begin{array}{l}\text { Gender } \\
\quad \text { Male }\end{array} \quad 34$ & 75.6 \\
$\quad$ Female & 11 & 24.4 \\
Etiology & & \\
$\quad$ Accident & 32 & 71.1 \\
$\quad$ Suicide & 13 & 28.9 \\
Accident origin (n=32) & & \\
$\quad$ Construction & 19 & 59.4 \\
$\quad$ Ladder & 7 & 21.8 \\
$\quad$ Tree & 4 & 12.5 \\
$\quad$ Electricity pylon & 2 & 6.3 \\
\hline & Mean \pm SD & Median (min-max) \\
\hline Age (year) & $37 \pm 16.2$ & $32(17-72)$ \\
Weight (kg) & $74 \pm 10.1$ & $75(50-95)$ \\
Height (cm) & $170 \pm 6.1$ & $170(160-185)$ \\
Body mass index & $25 \pm 3.3$ & $24.8(19.5-37.1)$ \\
Height of the fall (m) & $9 \pm 5.9$ & $8(2-30)$ \\
Hospital stay (days) & $13 \pm 13.8$ & $10(1-76)$ \\
\hline
\end{tabular}

SD: Standard deviation. 
Table 2. Other injury regions and grades with abdominal injury of 45 patients

\begin{tabular}{lccc}
\hline Injury regions & $\mathbf{n}$ & $\%$ & Injury grades, median (min-max) \\
\hline Head-neck & 25 & 55.6 & $3(1-5)$ \\
Face & 13 & 28.9 & $2(1-3)$ \\
Thorax & 37 & 82.2 & $3(2-5)$ \\
Abdomen & 45 & 100 & $4(1-5)$ \\
Extremity & 32 & 71.1 & $3(1-5)$ \\
External & 16 & 35.6 & $1(1-4)$ \\
\hline
\end{tabular}

Min: Minimum; Max: Maximum

by laceration of the liver $(n=20,44.4 \%)$, laceration of the kidney $(n=14,31.1 \%)$, retroperitoneal hematoma $(n=7,15.6 \%)$, laceration of the intestinal meso $(n=4,8.9 \%)$, injury of the small intestine $(n=3,6.7 \%)$, injury of the stomach $(n=2,4.4 \%)$, laceration of the urinary bladder $(n=2,4.4 \%)$, injury of the colon $(n=I, 2.2 \%)$, injury of the diaphragm $(n=I, 2.2 \%)$, and vascular trauma $(n=I, 2.2 \%)$.
The recovery group included 35 (77\%) cases, and the exitus group comprised $10(23 \%)$ cases. There was no statistically significant difference between the two groups in terms of age, gender, cause of the fall, and height of the fall $(p>0.05)$, whereas there was a statistically significant difference with respect to weight and $B M I$ values $(p<0.0 I)$. The weight and $\mathrm{BMI}$ values of the patients in the mortality group were significantly higher than those of the patients in the recovery group. Although there seemed to be higher values of height of the fall in the mortality group, no statistically significant difference was found between the two groups ( $p>0.05)$. The hospital stay was significantly shorter, but the rate of postoperative complications was higher in the mortality group than in the recovery group $(p<0.01)$ (Table 3$)$.

There was no difference between the two groups in the distribution of the head and neck, thorax, abdomen, extremity, and external trauma scores $(p>0.05)$. A statistically significant difference was found with respect to the trauma scores of the head and neck, thorax, abdomen, and extremity $(p<0.05)$. The head and neck, thorax, abdomen, and extremity trauma

Table 3. Comparison of the demographic data of the two groups

\begin{tabular}{|c|c|c|c|c|c|}
\hline & \multicolumn{2}{|c|}{ Recovery $(n=35)$} & \multicolumn{2}{|c|}{ Mortality $(n=10)$} & \multirow[t]{2}{*}{$\mathbf{p}^{*}$} \\
\hline & Mean $\pm S D$ & Median (min-max) & Mean \pm SD & Median (min-max) & \\
\hline Age (year) & $36.37 \pm 15.75$ & $32(17-72)$ & $39.40 \pm 18.52$ & $35.5(17-70)$ & 0.683 \\
\hline Weight (kg) & $72.31 \pm 10.19$ & $72(50-95)$ & $81.0 \pm 6.58$ & $85(70-90)$ & 0.004 \\
\hline Height (cm) & $170.49 \pm 5.57$ & $170(160-180)$ & $172.10 \pm 8.23$ & $172(160-185)$ & 0.600 \\
\hline Body mass index & $24.8 I \pm 3.26$ & $24(19.50-37.10)$ & $27.30 \pm 2.92$ & $27.6(22-33.20)$ & 0.008 \\
\hline Height of fall (m) & $8.03 \pm 4.64$ & $8(2-20)$ & $12.80 \pm 8.57$ & $13(3-30)$ & 0.088 \\
\hline Length of hospital stay (days) & $16.14 \pm 14.34$ & $12(3-76)$ & $5.0 \pm 7.19$ & $1.5(I-23)$ & 0.000 \\
\hline
\end{tabular}

* $p<0.05$. SD: Standard deviation; Min: Minimum; Max: Maximum.

Table 4. Comparison of the trauma scores of the two groups

\begin{tabular}{|c|c|c|c|c|c|}
\hline & \multicolumn{2}{|c|}{ Recovery $(n=35)$} & \multicolumn{2}{|c|}{ Mortality $(n=10)$} & \multirow[t]{2}{*}{$\mathbf{p}^{*}$} \\
\hline & Mean $\pm S D$ & Median (min-max) & Mean $\pm S D$ & Median (min-max) & \\
\hline Injury Severity Score & $28.51 \pm 12.39$ & $27(10-59)$ & $45.30 \pm 20.19$ & $44.5(20-75)$ & 0.023 \\
\hline New Injury Severity Score & $31.57 \pm 15.77$ & $27(10-75)$ & $49.10 \pm 20.71$ & $46.5(20-75)$ & 0.021 \\
\hline Glascow Coma Scale & $14.0 \pm 1.78$ & $15(8-15)$ & $10.70 \pm 4.37$ & $12.5(4-15)$ & 0.019 \\
\hline Revised Trauma Score & $7.45 \pm 0.82$ & $7.84(5.15-7.84)$ & $6.14 \pm 1.76$ & $6.35(3.63-7.84)$ & 0.028 \\
\hline Abbreviated Injury Score & $2.92 \pm 0.88$ & $3(I-5)$ & $4.02 \pm 0.67$ & $4(I-5)$ & 0.018 \\
\hline - Head and neck & $2.79 \pm 0.96$ & $2(I-4)$ & $3.43 \pm 1.27$ & $4(I-5)$ & 0.034 \\
\hline - Thorax & $2.76 \pm 0.79$ & $3(2-5)$ & $3.50 \pm 1.07$ & $4(2-5)$ & 0.073 \\
\hline - Abdomen & $3.31 \pm 0.77$ & $3(I-5)$ & $4.40 \pm 0.52$ & $4(4-5)$ & 0.000 \\
\hline - Extremity & $3.23 \pm 0.95$ & $3(I-5)$ & $4.33 \pm 0.82$ & $4(3-5)$ & 0.019 \\
\hline
\end{tabular}

${ }^{*} \mathrm{p}<0.05$. SD: Standard deviation; Min: Minimum; Max: Maximum. 
scores were significantly higher in the mortality group. There was a significant difference between the groups in terms of ISS, NISS, GCS, AIS, and RTS scores $(p<0.05)$ (Table 4).

\section{DISCUSSION}

Abdominal injuries are the third most common cause of death in trauma-related incidents. ${ }^{[7]}$ An early diagnosis followed by the appropriate treatment can reduce mortality rates by up to $50 \% .{ }^{[8]}$ The timing in the evaluation of trauma cases, using accurate imaging methods, trauma algorithms, and scoring systems are important in emergency departments, although they can change over time. ${ }^{[9,10]}$

A fall from height is defined as a free vertical fall from a height of $\geq 2 \mathrm{~m}$. ${ }^{\left[{ }^{I}\right]}$ Patients presenting with fall from height are also susceptible to deceleration injuries as well as direct impact injuries. The kinetic energy $(\mathrm{KE}=\mathrm{I} / 2 \mathrm{mV} 2)$ of the fall depends on body mass and height. ${ }^{[12]}$ Similarly, as the height increases, the free body mass accelerates due to gravity $(v=\sqrt{ }(2 g h))$, and its velocity increases. ${ }^{[13]}$

The mortality rate reported in patients with fall from height depends on the height of the fall and the methodology of the study. Higher mortality rates have been reported in a series where patients have been lost at the scene or during transfer. Liu et al. ${ }^{[14]}$ reported a mortality rate of $22.7 \%$ in a series of patients falling from a height of $>6 \mathrm{~m}$. In addition, Lapostolle et al. ${ }^{[3]}$ reported a $34 \%$ mortality rate in patients falling from $>3 \mathrm{~m}$. However, in another study, the hospital mortality rate was reported as $9.6 \%$ for falls from $>6 \mathrm{~m}^{\left[{ }^{[5]}\right.}$ In the current study, there was no statistically significant difference with respect to the height of the fall. However, it may be that the average height of the fall in both groups was above the critical height of $6 \mathrm{~m}$.

Literature has shown that major abdominal injuries are rare, but solid organ injuries (liver, spleen, and kidney) are particularly associated with high morbidity and mortality rates. ${ }^{\left[{ }^{\prime \prime}\right]}$ In an autopsy series by Jagannatha et al., ${ }^{[16]}$ it was reported that liver and spleen injuries occur at heights $>24 \mathrm{~m}$ regardless of their effect type. Abdominal injuries are associated with a poor outcome, but it has been reported that survival may improve with immediate surgical exploration in hemodynamically unstable patients. ${ }^{[1]}$ In the current study, which similarly included hemodynamically unstable patents, the injuries recorded were mostly from spleen, liver, and renal laceration. When the results of the present study are evaluated, the effect of weight and BMI on mortality in patients with fall from height can be clearly seen. These parameters were considered to have an effect on the kinetic energy generated during the fall from height. ${ }^{[12]}$ Obese patients appear to have a higher risk of mortality after a fall from height; therefore, the present study may provide data for stronger preventive measures against falls for obese patients. On the other hand, recently, the effect of BMI on over a hundred thousand patients after emergency surgery was analyzed. It has been concluded that obesity is associated with increased morbidity, whereas overweight and class I obesity are protective. ${ }^{[1]}$

In the current study, the hospital stay in the mortality group was significantly lower, and the complication rate was significantly higher than those in the recovery group. The head and neck, thorax, abdomen, and extremity trauma grades were significantly higher in the mortality group. Ground contact in a fall from height usually occurs against the head and chest as these are the lowest points of gravity of the human body, and craniocerebral injuries are one of the major causes of mortality. ${ }^{[18]}$ In falls from average height, the frequency of impacts on the chest region increases. ${ }^{[12,19]}$ Içer et al. ${ }^{[4]}$ reported that hemopneumothorax and subarachnoid hemorrhage are the most important independent risk factors affecting mortality.

TSSs are commonly used to determine the severity of any trauma. In the evaluation of trauma scores, the association of ISS with increasing height variable has been previously reported. ${ }^{\left[{ }^{\prime \prime}\right]}$ Beale et al. showed clearly numerically that an ISS of $\geq 50$ is uniformly associated with death. Eryılmaz et al. $^{[20]}$ compared trauma scores in terms of fall from height and reported that the areas under the curve are 0.910 for ISS and 0.915 for NISS in ROC analysis. Dickinson et al. ${ }^{[12]}$ also reported that the height of the fall is correlated with the ISS score. Liu et al. ${ }^{[14]}$ stated that an ISS score of $\geq 16$ in patients falling from a height of $>6 \mathrm{~m}$ is one of the factors significantly correlated with mortality in univariate analysis, and a head/neck AIS of $\geq 4$ is independently correlated with the final mortality rate in multivariate analysis. In addition, in blunt abdominal trauma, the association with mortality of high ISS values due to gastrointestinal system injuries has been described. ${ }^{[21]}$

There have been many recent developments in radiological and laboratory evaluation methods for patients with multiple trauma, and these methods are expected to be increasingly helpful for quick decision-making and the management of patients with trauma. Based on these evaluations, scoring systems and treatment algorithms have been developed to be able to approach patients with trauma in the most appropriate way. The factors examined in the present study can be considered useful for the development of algorithms and standardization. It is important to define the cut-off values of injury scores and, thereby, identify high-risk groups in order to establish more extensive preventive measures if possible and to make triage decisions for early transfer, early surgery, and other extreme situations requiring difficult decisions. Many factors determine the severity of injury and mortality in a fall from height.

In the present study, the importance of weight and BMI was examined on mortality rate. However, as different age and gender groups are affected differently by each of these variables, there are still many issues that require further investi- 
gation. Therefore, there is a need for multicentered studies with extensive case series in order to determine the factors affecting morbidity and mortality and to be able to generate algorithms and guidelines based on the diagnosis, follow-up, and treatment processes of the patients.

\section{Conflict of interest: None declared.}

\section{REFERENCES}

1. Curry N, Davis PW. What's new in resuscitation strategies for the patient with multiple trauma? Injury 2012;43:1021-8. [CrossRef]

2. Güneş Tatar İ, Yilmaz KB, Ergun O, Balas Ş, Akinci M, Deryol R, et al. The effect of clinical, laboratory and radiologic results on treatment decision and surgical results in patients admitted to the emergency department with blunt abdominal trauma due to traffic accident [Article in Turkish]. Ulus Travma Acil Cerrahi Derg 2015;21:256-60.

3. Lapostolle F, Gere C, Borron SW, Pétrovic T, Dallemagne F, Beruben A, et al. Prognostic factors in victims of falls from height. Crit Care Med 2005;33:1239-42. [CrossRef]

4. Içer M, Güloğlu C, Orak M, Ustündağ M. Factors affecting mortality caused by falls from height. Ulus Travma Acil Cerrahi Derg 2013;19:529-35. [CrossRef]

5. Wisner DH. History and current status of trauma scoring systems. Arch Surg 1992;127:111-7. [CrossRef]

6. Bond RJ, Kortbeek JB, Preshaw RM. Field trauma triage: combining mechanism of injury with the prehospital index for an improved trauma triage tool. J Trauma 1997;43:283-7. [CrossRef]

7. Shojaee M, Faridaalaee G, Yousefifard M, Yaseri M, Arhami Dolatabadi A, Sabzghabaei A, et al. New scoring system for intra-abdominal injury diagnosis after blunt trauma. Chin J Traumatol 2014;17:19-24.

8. Chardoli M, Rahimi-Movaghar V. Analysis of trauma outcome at a university hospital in Zahedan, Iran using the TRISS method. East Afr Med J 2006;83:440-2. [CrossRef]

9. Martí De Gracia M, Artigas Martín JM, Vicente Bártulos A, Carreras Aja
M. Radiological management of patients with multiple trauma: history and current practice [Article in Spanish]. Radiologia 2010;52:105-14.

10. van Schuppen J, Olthof DC, Wilde JC, Beenen LF, van Rijn RR, Goslings JC. Diagnostic accuracy of a step-up imaging strategy in pediatric patients with blunt abdominal trauma. Eur J Radiol 2014;83:206-11.

11. Beale JP, Wyatt JP, Beard D, Busuttil A, Graham CA. A five year study of high falls in Edinburgh. Injury 2000;31:503-8. [CrossRef]

12. Dickinson A, Roberts M, Kumar A, Weaver A, Lockey DJ. Falls from height: injury and mortality. J R Army Med Corps 2012;158:123-7.

13. Kepler CK, Nho SJ, Miller AN, Barie PS, Lyden JP. Orthopaedic injuries associated with fall from floor forty-seven. J Orthop Trauma 2009;23:154-8. [CrossRef]

14. Liu CC, Wang CY, Shih HC, Wen YS, Wu JJ, Huang CI, et al. Prognostic factors for mortality following falls from height. Injury 2009;40:595-7.

15. Velmahos GC, Demetriades D, Theodorou D, Cornwell EE 3rd, Belzberg $\mathrm{H}$, Asensio J, et al. Patterns of injury in victims of urban free-falls. World J Surg 1997;21:816-20. [CrossRef]

16. Jagannatha SR, Pradeep Kumar MV, Naveen Kumar T, Ananda K, Venkatesha VT. Injuries due to fall from height - a retrospective study. Journal of Forensic Medicine and Toxicology 2010;27:47-50.

17. Benjamin ER, Dilektasli E, Haltmeier T, Beale E, Inaba K, Demetriades $\mathrm{D}$. The effects of body mass index on complications and mortality after emergency abdominal operations: The obesity paradox. Am J Surg 2017;214:899-903. [CrossRef]

18. Kusior ME, Pejka K, Knapik M, Sajuk N, Kłaptocz S, Konopka T. Anal$y$ sis of the nature of injuries in victims of fell from height. Arch Med Sadowej Kryminol 2016;66:106-24. [CrossRef]

19. Risser D, Bönsch A, Schneider B, Bauer G. Risk of dying after a free fall from height. Forensic Sci Int 1996;78:187-91. [CrossRef]

20. Eryılmaz M, Durusu M, Menteş Ö, Özer T, Kılıç S, Ersoy G, et al. Comparison of trauma scores for adults who fell from height as survival predictivity. Turk J Med Sci 2009;39:247-52.

21. Al-Hassani A, Tuma M, Mahmood I, Afifi I, Almadani A, El-Menyar A, et al. Dilemma of blunt bowel injury: what are the factors affecting early diagnosis and outcomes. Am Surg 2013;79:922-7.

\section{ORIJIINAL ÇALIŞMA - ÖZET}

\section{Yüksekten düşme olgularında mortaliteye neden olan faktörler}

\section{Dr. Muzaffer Akkoca, Dr. Serhat Tokgöz, Dr. Kerim Bora Yılmaz, Dr. Sümeyra Güler, Dr. Melih Akıncı, Dr. Şener Balas, Dr. Harun Karabacak, Dr. Mehmet Saydam}

SBÜ Dışkapı Yıldııım Beyazıt Eğitim ve Araştırma Hastanesi, Genel Cerrahi Kliniği, Ankara

AMAÇ: Bu çalışmada vücut kitle indeksi (VKi) ve Travma Derecesi Skorlama Sistemi'nin yüksekten düşme nedeniyle ameliyat edilen hastaların mortalite oranları üzerindeki rolü araştıııldı.

GEREÇ VE YÖNTEM: Bu geriye dönük çalışma, Ocak 2008 ile Aralık 2016 tarihleri arasında yüksekten düşme nedeniyle başvuran ve ameliyat edilen, çoklu travmalı 45 ardışık erişkin hastayı içermiştir. Hastalar mortalite ve yaşayan gruplarına ayrılmıştır ( $n=10, n=35$, sırasıyla). Gruplar yaş, cinsiyet, kilo, düşme nedeni, düşme yüksekliği, düşme yeri, VKi, Travma Skorları (Injury Severity Score [ISS], New Injury Severity Score [NISS], Glasgow Coma Scale [GCS], Abbreviated Injury Score [AIS], Revised Trauma Score [RTS]), hastanede kalıs süresi ve ameliyat sonrası komplikasyonlar açısından karşılaştırıldı.

BULGULAR: Her iki grup arasında yaş, cinsiyet, boy veya düşme nedeni açısından istatistiksel olarak anlamlı fark bulunmazken ( $p>0.05)$, kilo ve VKi değerleri açısından istatistiksel olarak anlamlı fark saptandı $(p<0.01)$. Gruplar arasında hastanede kalış süresi ve ameliyat sonrası komplikasyonlar açısından ( $p<0.01)$, ISS, NISS, GCS, AIS ve RTS skorları açısından istatistiksel olarak anlamlı fark saptandı $(p<0.05)$.

TARTIŞMA: Bu çalışmada, yüksekten düşme sonucu travma ile başvuran hastaların vücut ağırlığı ve VKl'nin mortalite üzerine etkisi objektif olarak gösterilmiştir.

Anahtar sözcükler: Mortalite; Travma Skoru; vücut kitle indeksi; yüksekten düşme.

Ulus Travma Acil Cerrahi Derg 20 18;24(5):445-449 doi: 10.5505/tjtes.20I8.50724 